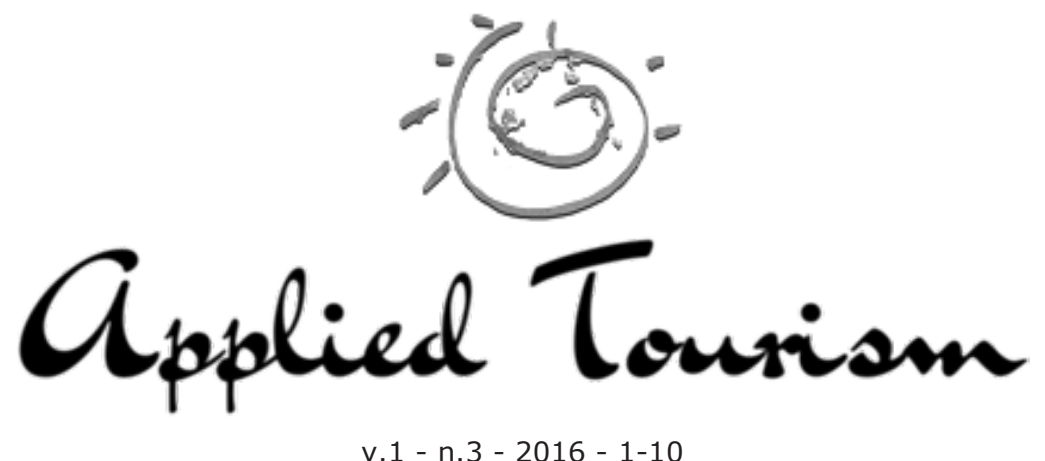

v. $1-\mathrm{n} .3-2016-1-10$

\title{
LUDICIDADE E TURISMO: UM JOGO PARA APRESENTAR ROTEIROS DE TURISMO GASTRONÔMICO NA CIDADE DE PELOTAS
}

\section{PLAYFULNESS AND TOURISM: A GAME FOR PRESENTING GASTRONOMIC TOURISM IN PELOTAS - BRAZIL}

\author{
Marina Berton - Bacharel em Turismo \\ Universidade Federal de Pelotas. mahmbrtn@gmail.com \\ Carina Pardi Ustárroz - Bacharel em Turismo \\ Universidade Federal de Pelotas. carina.pardi.ustarroz@hotmail.com \\ Bruna Frio Costa - Mestra em Memória Social e Patrimônio Cultural \\ Universidade Federal de Pelotas. brunafriocosta@gmail.com
}

Recebido/Received: 08/08/2016 - Aprovação/Approval: 12/12/2016

\begin{abstract}
RESUMO: Os jogos educacionais são utilizados como forma de facilitar a compreensão da educação turística, inclusive quando utilizado com adultos. 0 objetivo deste trabalho é apresentar o jogo educacional criado em sala de aula pelos alunos da disciplina de Turismo Gastronômico, do Curso de Bacharelado em Turismo da Universidade Federal de Pelotas no segundo semestre de 2015, e os benefícios que tal prática apresenta para quem cria e quem joga. Acredita-se que a prática influenciará na qualidade da educação e na atuação dos futuros profissionais - tanto do turismo, quanto da gastronomia - no mercado. Além
\end{abstract}

\begin{abstract}
Educational games are used as a way to facilitate understanding of tourism education, including when it is used with adults. This paper's objective is to present the educational game created in class by students of Gastronomic Tourism, a course from the Tourism Program at UFPEL (Pelotas Federal University), during the second semester of 2015, and the benefits that the practice presents to who creates and who plays. It is expected that the practice will influence on the quality of education and the performance of the future professionals - both tourism and gastronomy - on the market. This game can also be - used by the project "Ludoteca do Turismo" (Tourism Toy Library), on the Patrimonial Week of Pelotas; in academic events or submitted to the Pelotas Economic Development
\end{abstract}


de poder ser utilizado pelo Projeto Ludoteca do Turismo, na Semana do Patrimônio de Pelotas, em eventos acadêmicos, e poderá ser entregue à Secretaria de Desenvolvimento Econômico e Turismo de Pelotas como forma de auxiliar no desenvolvimento do turismo e da gastronomia de Pelotas.

Palavras-chave: Turismo Gastronômico; Roteiros; Educação Turística; Jogos Educacionais; Pelotas

\section{INTRODUÇÃO}

Um dos grandes desafios que se apresentam no universo dos cursos superiores e para todo o processo de ensino e aprendizagem é aliar a teoria da sala de aula e a prática cotidiana. De acordo com Prosser e Trigweel (1999), a forma como o conhecimento é transmitido influencia a qualidade da educação e a atuação dos futuros profissionais no mercado. De maneira geral, as empresas esperam que seus profissionais sejam devidamente qualificados para o exercício de suas funções, contando com uma formação abrangente e atual, em conformidade com as demandas do mercado (Souza \& Guerra, 2006). O ensino do Turismo vem incentivando o equilíbrio entre teoria e prática, visto que esta é uma área dinâmica que necessita aliar os conhecimentos às vivências do dia-a-dia de um turismólogo.

O objetivo deste trabalho é apresentar o jogo educacional, criado em sala de aula pelos alunos dos cursos de Turismo e Gastronomia, da disciplina de Turismo Gastronômico, bem como ressaltar a importância da ludicidade, até mesmo na fase adulta, para o desenvolvimento de conhecimentos mais concretos, inseridos na realidade.

Tal opção justifica-se no pensamento de Behrens (1996) ao afirmar que a fim de contribuir para a qualidade do ensinoaprendizagem, a ação de um professor deve ser orientada por metodologias que ultrapassem a reprodução do conhecimento e busquem autonomia e criatividade.

Acredita-se que a perfeita interface entre $o$ mundo do teórico e a realidade se mostra um instrumento fundamental para que o egresso tenha reais possibilidades de progresso no campo do trabalho.

Este artigo apresenta, primeiramente, conceitos sobre a Educação Turística, jogos e ludicidade, principalmente relacionadas aos adultos. Foram analisados dois roteiros and Tourism Bureau, as a way to assist the tourism and gastronomy development in Pelotas.

Keywords: Gastronomic Tourism; Itineraries; Tourism Education; Educational Games; Pelotas.

\section{INTRODUCTION}

One of the main challenges faced by higher education and in the teaching and learning processes as a whole is to combine classroom theory and everyday practice. According to Prosser and Trigwell (1999), how knowledge is shared influences the quality of education and the performance of future professionals in the market. In general, companies expect their professionals to be properly qualified to perform their duties, with a comprehensive training that meets the market demands (Souza \& Guerra, 2006). Tourism teaching has been encouraging the balance between theory and practice, as this is a dynamic field that needs to combine knowledge with experiences of the daily life of a tourism specialist.

This paper presents an educational game developed in the classroom by students of Tourism and Gastronomy for the Gastronomic Tourism course. It also emphasizes the importance of playfulness - even in adulthood - to the development of a more concrete knowledge, closely linked to reality.

This option is justified in Behrens (1996), who claims that in order to contribute to the quality of teaching and learning, the teacher should be guided by methodologies that go beyond the reproduction of knowledge and seek autonomy and creativity.

The perfect interface between theory and reality is believed to be a key instrument for the graduate to have a real chance of progress in his field of study.

This paper first introduces concepts of Tourism Education, games and playfulness, mainly related to adults. Two itineraries and a game planned by the professor Bruna Frio Costa and developed in the Gastronomic Tourism course were analyzed, which was offered in the second semester of 2015. There were a total of 18 students of Tourism and of Gastronomy from UFPEL.

The development of itineraries and games established a partnership between both programs, which also made the classes more interesting and enabled the development of more authentic ideas, since other touristic and gastronomic areas in the city of Pelotas gained 
e um jogo, propostos pela Professora Mestra Bruna Frio Costa, elaborados a partir da disciplina de Turismo Gastronômico, ofertada no segundo semestre de 2015 , com um total de 18 alunos, sendo oriundos dos cursos de Turismo e Gastronomia da Universidade Federal de Pelotas.

A criação dos roteiros e do jogo culminou na integração e parceria entre estes dois cursos, além de tornar as aulas mais atrativas e possibilitar a elaboração de algo mais autêntico, uma vez que foram analisados outros espaços turísticos e gastronômicos de Pelotas, olhados sob uma nova perspectiva. Intentava-se, com a elaboração do jogo, que ele fosse além dos muros da universidade: que também possa ser apresentado em eventos acadêmicos, utilizados em projetos de extensão e apresentado para a comunidade em geral.

\section{A IMPORTÂNCIA DA EDUCAÇÃO TURÍSTICA E DOS JOGOS EDUCACIONAIS}

A Educação Turística é de suma importância, afinal, propaga o conhecimento turístico envolvendo as mais diversas pessoas, incluindo e ajudando no desenvolvimento sustentável do turismo.

Rebelo (1998 apud Fonseca Filho, 2007, p. 19) explica que a Educação Turística pode ser definida como "um processo educativo cuja finalidade é de difundir conhecimentos sobre a atividade turística em cidades turísticas ou com potencial turístico".

A Educação Turística, para Fonseca Filho (2007, p. 31), tem o papel de difundir os conhecimentos de turismo em alguma localidade, onde o intuito é de envolver os munícipes com a cultura dos mesmos e com o turismo, assim formando cidadãos "responsáveis e protetores de seus patrimônios culturais (patrimônios históricos, culturais, intangíveis e naturais) além de bons anfitriões de visitantes e turistas". O autor acrescenta:

O objetivo central da educação turística é educar os munícipes e turistas para o desenvolvimento sustentável do turismo, contribuindo para que todos desenvolvam comportamentos responsáveis e coerentes diante da atividade turística. (Fonseca Filho, 2007, p. 20)

E enfatiza, "o ensino do turismo pode ser uma prática pedagógica direcionada para complementar a formação dos educandos, visando o preparo destes para um mudo a different perspective. The intention behind the game was to go beyond the classroom and present it at academic events, use it in extension programs and make it available to the community as a whole.

\section{THE IMPORTANCE OF TOURISM EDUCATION AND EDUCATIONAL GAMES}

Tourism Education is of paramount importance, after all it spreads tourism knowledge involving several people and stimulates sustainable tourism development.

Rebelo (1998 apud Fonseca Filho, 2007, p. 19) explains that Tourism Education can be defined as "an educational process whose purpose is to disseminate knowledge about tourism in potential tourist destinations".

Fonseca Filho (2007, p. 31) says Tourism Education plays the role of spreading tourism knowledge in some location in order to get citizens involved with their own culture and with tourism, thereby forming citizens who are "responsible for and protectors of their cultural heritage (historical, cultural, intangible and natural heritages) and also good hosts to visitors and tourists". He adds:

The main purpose of tourism education is to educate citizens and tourists on sustainable tourism development, helping everyone to develop responsible and consistent behavior towards tourism. (Fonseca Filho, 2007, p. 20)

He emphasizes that "tourism education can be a pedagogical practice directed to complementing the training of students, preparing them for a multicultural and globalized world" (Fonseca Filho, 2007, p. 11).

It is difficult for adults in general to see games and activities as a way to learn, since they are regarded as the opposite of work. According to Beauchamp, Pagel \& Nascimento (2007, p. 35):

Children's games are among the
activities often regarded as a waste of
time. Why does it happen? Well, such a
view is a result of the idea that games
are the opposite of work and thus, they
are less important, since they are not
related to the world of productivity and
that is why they do not produce results.
(Beuchamp, Pagel \& Nascimento, 2007,
p. 35)

The authors (p. 38) also explain that it is through games that one learns to play, and it 
multicultural e globalizado" (Fonseca Filho, 2007, p. 11).

Para os adultos em geral, há uma dificuldade de enxergar uma forma de aprendizado na brincadeira ou no jogo, pois os mesmos são vistos como opostos ao trabalho. Segundo Beuchamp, Pagel \& Nascimento (2007, p. 35):

\begin{abstract}
A brincadeira está entre as atividades frequentemente avaliadas por nós como tempo perdido. Por que isso ocorre? Ora, esta visão é fruto da ideia de que a brincadeira é uma atividade oposta ao trabalho, sendo por isso menos importante, uma vez que não se vincula ao mundo produtivo, não gera resultados. (Beuchamp \& Pagel \& Nascimento, 2007, p. 35)
\end{abstract}

Os autores (p. 38) ainda explicam que através da brincadeira é que se aprende a brincar, e a partir da interação com os outros, observação e participação das brincadeiras, que "vamos nos apropriando tanto dos processos básicos constitutivos do brincar, como dos modos particulares de brincadeira, ou seja, das rotinas, regras e universos simbólicos", que acabam por caracterizar e especificar os grupos sociais nos quais inserimo-nos.

Beuchamp, Pagel \& Nascimento (2007, p. 42) completam que o ato de brincar é "uma experiência de cultura importante não apenas nos primeiros anos da infância, mas durante todo o percurso de vida de qualquer ser humano", sendo importante assim, e devendo ser garantida em todos os anos, inclusive após o período de infância, incluindo os anos de ensino fundamental e as etapas subsequentes da formação de todos.

São considerados Jogos Educacionais as "aplicações que puderem ser utilizadas para algum objetivo educacional e estiverem pedagogicamente embasadas, mostrandose como motivadores do processo de aprendizagem" (Tarouco, Konrath \& Grando, 2005, p. 4). Os mesmos jogos podem ser utilizados em projetos que são contextualizados, interdisciplinares, e também para a resolução de problemas sendo que a "utilização desses novos recursos modifica a dinâmica do ensino, as estratégias e o comprometimento de alunos e professores". Os autores completam que com esses novos recursos e ferramentas "a educação pode ensejar uma aprendizagem construtiva e significativa, na qual o aluno pode aprender de forma mais dinâmica e motivadora". is through interacting with others, observing and taking part in games that "we gradually assimilate the basic constituent processes of playing and the specific modes of playing, i.e. routines, rules and symbolic universes", which ultimately characterize and specify the social groups one fits in.

Beuchamp, Pagel \& Nascimento (2007, p. 42) further explain that the act of playing is "a major cultural experience that is important not only in early childhood but also throughout the course of life of any human being" So it is important and it must be ensured in every year, even after childhood, including the years of elementary school and the subsequent stages.

Educational games can be described as "applications that can be used for any educational purpose and that are pedagogically informed, being motivators of the learning process" (Tarouco, Konrath \& Grando, 2005, p. 4). Those same games can be used in projects that are contextualized and interdisciplinary, and also for solving problems given that the "use of these new features changes the dynamics of teaching strategies and the commitment of students and teachers." The authors add that with these new features and tools "education can rise to a constructive and meaningful learning, in which students can learn in a more dynamic and motivating way."

According to Tarouco, Konrath \& Grando (2005, p. 5), Educational Games may be adopted in pedagogical practice and they involve the reality of students by contextualizing classroom activities, as well as being pedagogically informed.

Ferreira (2004) elaborates:

Most adult men refrain themselves from being spontaneous and showing their emotions, creativity and playfulness because of the demands (obligation) of a society that says adulthood is all about seriousness and obligations. Contrary to that tendency, some adults seem to have overcome those barriers; they do not mind judgment and do whatever suits them, thus they draw the attention of others. Consequently, they get to fully experience playfulness in the social context of leisure hours. (Ferreira, 2004, p. 5-6)

The number of adults who actually experience playfulness is still small, since the overstated use of reason is historically 
De acordo com Tarouco, Konrath \& Grando (2005, p. 5), os Jogos Educacionais poderão ser inseridos na prática pedagógica, envolvendo a realidade dos alunos, a partir de contextualização das atividades trabalhadas na sala de aula, e estando pedagogicamente embasadas.

Ferreira (2004) explica que:

a maioria dos adultos homens se contém, não se permitem agir de maneira espontânea, não expressam assim suas emoções, criatividade e ludicidade devido às exigências (obrigatoriedade) que se tem em seguir às normas impostas pela sociedade, que a fase adulta é a fase da seriedade, das obrigações. Contraditoriamente a isso percebeu-se de forma clara que alguns adultos quebram essas barreiras, não se incomodando com o julgamento dos outros, fazendo o que lhes convém, ou seja, chamam a atenção de todos que estão ao seu redor. Dessa forma acabam vivenciando a ludicidade plenamente dentro de um dos interesses do lazer - o social. (Ferreira, 2004, p. 5-6)

O número de adultos que realmente vivenciam a ludicidade é reduzido, tendo em vista o uso exagerado da razão, ideia esta construída historicamente pelos homens como uma das condições básicas para pertencerem à humanidade. Além disso, a ludicidade poderia "aflorar" em qualquer idade, porém, com as "couraças sociais, dos preconceitos, das regras e da própria história do homem na sociedade esta ludicidade pouco é percebida nos adultos", e quando ela existe, é "ridicularizada pelo próprio adulto ou pelo meio em que este está inserido" (Da Costa, n.d, p. 07).

Os jogos podem facilitar o aprendizado, visto que o aluno consegue prestar mais atenção e ter interesse, por ser uma atividade lúdica. Falkembach (n.d) explica que:

Em um jogo a carga informativa pode ser significantemente maior, os apelos sensoriais podem ser multiplicados e isso faz com que a atenção e o interesse do aluno sejam mantidos, promovendo a retenção da informação e facilitando a aprendizagem. Portanto, toda a atividade que incorporar a ludicidade pode se tornar um recurso facilitador do processo de ensino e aprendizagem. (Falkembach, n.d, p. 1)

Falkembach (n.d, p. 2) completa que "jogando a criança, o jovem ou mesmo o adulto sempre aprende algo, sejam habilidades, construed by men as a basic condition for belonging in society. Furthermore, playfulness could "emerge" at any age, but with the "social constraints, prejudices, rules and men's history in society, this playfulness can hardly be seen in adults", and when it is seen, it is "mocked by the adult himself or his environment" (Da Costa, n.d., p. 07).

Games can make learning easier, as the student can pay more attention and be interested in them because they are a playful activity. Falkembach (n.d.) explains:

In a game, the information charge can be significantly higher and senses can be sharpened, which causes the attention and interest of the student to be maintained by promoting information retention and making learning easier. Therefore, any activity that incorporates playfulness can become a facilitating resource for the teaching and learning processes. (Falkembach, n.d., p. 1)

Falkembach (n.d., p. 2) adds that "Children, teenagers and even adults always learn something when they play, whether are skills, values or attitudes, therefore, one can say that every game has something to teach". The author ( $p .3$ ) goes on explaining that educational games are based on leisure and fun, but with educational goals. Also, ( $p$. 3) "educational games increase the possibility of learning and help building confidence and increasing motivation in the learning context."

\section{A GAME TO PRESENT GASTRONOMIC TOURISM ROUTES IN PELOTAS}

The Tourism program at UFPEL requires the accomplishment of 3,143 hours in credits , including core courses, elective courses and extracurricular activities. The Gastronomic Tourism elective course is offered annually, and it attracts the interest and curiosity of students from both Tourism and Gastronomy programs. The Gastronomy program has a close relationship with tourism and contributes to further enrich this subject through the exchange of experiences and realities.

In the second semester of 2015, the Gastronomic Tourism course was offered and all the 18 available seats were filled. The course plans consist of arranging gastronomic itineraries, guided by theoretical and practical knowledge.

Professor Bruna Frio Costa, who is responsible for the course, suggested for the 
valores ou atitudes, portanto, pode-se dizer que todo jogo ensina algo". A autora (p. 3) ainda explica que os jogos educativos têm seu conteúdo e as atividades práticas baseadas no lazer e diversão, porém com objetivos educacionais. Além disso, (p. 3) os "jogos educacionais aumentam a possibilidade de aprendizagem além de auxiliar na construção da [sic] autoconfiança e incrementar a motivação no contexto da aprendizagem".

\section{UM JOGO PARA APRESENTAR ROTEIROS DE TURISMO GASTRONÔMICO NA CIDADE DE PELOTAS}

O curso de Turismo da Universidade Federal de Pelotas possui uma carga horária total de 3.143 horas, entre disciplinas obrigatórias, disciplinas optativas e atividades complementares. Entre as optativas, a disciplina de Turismo Gastronômico é ofertada anualmente, despertando o interesse e curiosidade dos alunos tanto do curso de Turismo como também do curso de Gastronomia - também oferecido pela Universidade - que possui uma estreita relação com a área do turismo e contribui para enriquecer ainda mais esta disciplina, na troca de experiências e realidades.

No segundo semestre do ano de 2015, a disciplina de Turismo Gastronômico foi ofertada, sendo que das 18 vagas disponibilizadas foram preenchidas. De acordo com a ementa, a disciplina consiste na formatação e desenvolvimento de rotas e roteiros gastronômicos, iluminados sob o conhecimento teórico-prático.

Foi proposto pela professora Mestra Bruna Frio Costa, responsável pela disciplina, na aula do dia 18 de setembro, que os alunos, em conjunto, elaborassem dois roteiros turísticos, que englobassem locais de interesse turístico e gastronômico na cidade de Pelotas, sob uma perspectiva diferente do foco que era geralmente utilizado.

A partir da solicitação da professora, a turma optou por dividir-se em dois grupos para que dois roteiros bem distintos fossem criados: um deles voltado para um público alvo de 35 a 50 anos e que apresentaria pontos turísticos já explorados pela cidade de Pelotas, além de restaurantes de alto padrão. O segundo roteiro buscava apresentar a cidade de Pelotas sob novo olhar, voltado class of September 18th that they would draw up two tourist itineraries that should include tourist and gastronomic attractions in the city of Pelotas, but from a new perspective.

The students decided to split into two groups so that two distinct itineraries were created: one of them was aimed at people between the ages from $35-50$ and would present attractions already known in the city of Pelotas and upscale restaurants. The second would present the city under a new perspective. It would be aimed at a younger target audience and would present "alternative" and low cost places, focusing on unexplored locations and including cheaper restaurants and leisure options.

The first itinerary lasts two days and presents three areas in Pelotas: Charqueada São João, where the Brazilian TV show "Casa das Sete Mulheres" (2002) and the movie "O tempo e o vento" (2012) were filmed ; Praia do Laranjal and Colônia. The itinerary would start with a boat trip to take the tourists to Charqueada São João, where the lunch served would be: fried cassava, a rice-withmeat (or arroz de carreteiro), bean stew (or feijoada), barbecue, traditional desserts, and other regional dishes. Then the tourists would be taken to Praia do Laranjal and Parque da Baronesa - some of the main attractions in the city. Dinner would be served at the restaurant "Mercado Del Puerto", which would serve a typical parrilla. The first day would end with the checking in at a pre-selected hotel. On the second day, the tourists would travel in the morning to the colony in Pelotas to have lunch at the restaurant and museum "Gruppelli", that serves typical dishes from Italian and German cuisine. Then they would visit the tourist spots on the countryside, such as the wine canteen "João Bento e Camelatto" and the traditional "Doces Crochemore" with its candied fruits and jams. At the end of the day the group would return to the hotel to check out and then return to their hometowns.

The second itinerary focused on the center area and Porto neighborhood. This single-day itinerary starts at noon and should take place preferably on Thursdays, Fridays or Saturdays, starting with a traditional lunch at "Café.com". Then there is a guided tour to the historical sites, such as the theaters, Sete de Abril and Guarany, Grande Hotel, the Public Library, Museu do Doce, the City Hall, Casarão 2, Casarão 4 and Casarão Assumpção Viana. The tour ends at the newly restored Public Market, 
ao público alvo jovem, com lugares mais "alternativos" e de baixo custo, ou seja, um roteiro que explora lugares desconhecidos ou pouco conhecidos, como opções baratas para comer e praticar o lazer.

O primeiro roteiro, com dois dias de duração, apresenta três regiões de Pelotas: a charqueada São João - onde ocorreram as gravações da minissérie da Rede Globo "Casa das Sete Mulheres" (2002) e do filme "O tempo e o vento" (2012), a Praia do Laranjal e a Colônia. O roteiro teria inicio com um passeio de barco que levaria os turistas até a Charqueada São João, onde seria servido o almoço: aipim frito, carreteiro de charque, feijoada, churrasco, ambrosias, entre outros pratos típicos da região. Em seguida, os turistas seriam levados até a praia do Laranjal e Parque da Baronesa - alguns dos principais pontos turísticos da cidade. O jantar ficaria sob responsabilidade do restaurante "Mercado Del Puerto", que serviria uma parrilla típica. $\mathrm{O}$ primeiro dia seria encerrado com check in em um hotel pré-estabelecido. No segundo e último dia, os turistas se deslocariam pela manhã até a colônia de Pelotas, para almoçar no restaurante e museu do "Gruppelli", com pratos típicos da culinária italiana e alemã. Em seguida visitariam os pontos turísticos do interior pelotense, como a cantina de vinhos "João Bento e Camelatto" e os "Doces Crochemore", com os tradicionais doces cristalizados e compotas. Ao final do dia o grupo retornaria ao hotel para check out e, em seguida, ocorreria o retorna às cidades de origem.

O segundo roteiro, optou por focar suas atividades em dois bairros da cidade de Pelotas: Centro e Porto. Com realização preferencialmente as quintas, sextas ou sábado, o roteiro de um dia inicia ao meio dia, com um tradicional A La Minuta da cidade, no "Café.com". Em seguida, ocorre uma visita guiada ao Centro Histórico, onde conheceriam o Theatro Sete de Abril, o Theatro Guarany, - Grande Hotel, a Biblioteca Pública, o Museu do Doce, a Prefeitura Municipal e os Casarões 2, 4 e Assumpção Viana. Encerrariam o tour no recém restaurado Mercado Público onde além do lanche da tarde, apreciariam a apresentação do grupo Renascença, no sempre convidativo "samba no mercado". O jantar, de livre escolha, ocorreria na Rua Gonçalves Chaves, um dos principais pontos de encontro da juventude. Ali, as opções gastronômicas são baratas e muito saborosas, além da "cerveja que nunca esquenta!" Este roteiro terminaria no conhecido Samba do Zé, where the tourists can enjoy an afternoon snack and a performance by the band Renascença, with the always pleasant "samba in the market." Dinner takes place at any restaurant on Gonçalves Chaves street, one of the main hot spots for young people, where the dining options are cheap and very tasty and "the beer never gets cold". This tour ends with Samba do Zé, in the popular Bar do Zé.

Those itinerary tours were developed not only so the students could understand the link between Tourism and Gastronomy and the role that this sector plays in the identity and local development of the community, but also so that they could see how the theory they have studied works in real life. For this reason, the idea was to turn both itineraries into a single game that could be played by people of any age to get to know the gastronomic tourist spots in Pelotas in a playful and fun way.

The game was inspired and adapted from Monopoly. A board game using A3 size printing of the locations where the itineraries take place was created, a dice and white sheets to be used as cards. Each location on the itineraries corresponds to a square on the board (FIGURE 1).

To start the game, a player throws the dice and moves according to the number indicated on the dice. If he lands on a location from the itinerary, the players get to hear about that place's history and some trivia.

This game provides the players with a broader knowledge of Gastronomic Tourism by ensuring that they learn about the more relevant places while also having a good time. The images are placed on the floor and each player is his own token (FIGURE 2).

There are also "trap" squares (FIGURE 3), such as "chance", "lunch", "parking", "hotel" get some rest, you got lost from the group. All the "traps" are related to Gastronomic Tourism (FIGURE 4): food poisoning - stay one round in the bathroom; lunch bonus, R\$ 40; sweet treat coupon, move to Mercado Público. If the player lands on the "hotel" square, he doesn't move for the next two rounds. If he lands on the "lunch" square, he pays a certain amount to the bank. The player who travels around all the squares from both itineraries is the winner.

\section{FINAL REMARKS}

The aim of this paper was to present the educational game developed by students of 
localizado no Bar do Zé, na região do Porto.

Estes roteiros foram criados não apenas para que os alunos percebessem a relação entre Turismo e Gastronomia, e a influência deste setor no desenvolvimento local e identitário da comunidade, mas, também, para que se obtivesse um respaldo prático, da teoria que fora estudada. Por esta razão, a proposta foi transformar os dois roteiros em um único jogo, o qual qualquer pessoa, de qualquer faixa etária, pudesse jogar para conhecer os pontos turísticos gastronômicos da cidade de Pelotas, de uma maneira lúdica e divertida.

O jogo criado foi uma adaptação dos jogos Banco Imobiliário e Monopoly. Para sua confecção, foram utilizadas impressões no tamanho A3 dos locais por onde os roteiros acontecem, um dado, e folhas brancas que serão as cartas de um baralho. Cada ponto dos roteiros era uma casa do tabuleiro (FIGURA 1 ).

Para iniciar é jogado o dado, conforme o número que cair, o jogador avança as casas. Se o jogador parar em uma casa onde tenha um lugar do roteiro, são lidas informações históricas e curiosidades sobre aquele local.

Este jogo, garante aos participantes um conhecimento mais amplo da área de Turismo Gastronômico, proporcionando a fixação dos lugares mais relevantes deste setor, divertindo e inteirando qualquer público. As impressões são colocadas no chão e cada jogador é o próprio "pino" (FIGURA 2).

Além destes lugares, também há casas "pegadinha" (FIGURA 3), como por exemplo: sorte ou azar, almoço, estacionamento, hotel - descanse, você se perdeu do grupo. Todas as "pegadinhas" são relacionadas ao Turismo Gastronômico (FIGURA 4): intoxicação alimentar, fique uma rodada no banheiro; bônus para o almoço, $\mathrm{R} \$ 40,00$; Vale um doce de Pelotas, avance até o Mercado Público. À casa "Hotel - descanse", o jogador fica duas rodadas sem jogar. Ou à casa "Almoço", ele paga um valor ao banco. Ganha o jogador que passar por todos os lugares dos dois roteiros.

\section{CONSIDERAÇÕES FINAIS}

O objetivo principal deste trabalho foi apresentar o jogo educacional criado pelos alunos para a disciplina de Turismo Gastronômico do Curso de Bacharelado em Turismo da Universidade Federal de Pelotas. Observouse que tal prática proporcionou à turma uma the Gastronomic Tourism course offered by the Tourism program at the Pelotas Federal University. This interaction fostered the relationship between the Tourism and Gastronomy programs, as students were able to exchange experiences from their previous individual knowledge of each field.

It is important to bring both fields closer together through interdisciplinary, as it was done in our study. The itineraries integrate and boost tourism in a city or region.

Playfulness - that facilitates learning in tourism education - was used as a teaching and learning method, aiming at a better use of the course. The itineraries and the game motivated the students to be more creative, expanding their perception of the city of Pelotas. Many of them had never been part of a game development project or an itinerary planning. This practice will have a positive effect on their education and their work as professionals.

It is expected that the game goes beyond the classroom and that it can be used in the project called Ludoteca do Turismo (Tourism Toy Library) developed by the Tourism program, which aims to develop educational play material related to the tourism sector for use in educational activities focused in tourism, in elementary schools and the community as a whole - reaching a larger target audience.

The itineraries can also be presented to new students in the University, especially students who are not from Pelotas, so that they can get to know a little more about the place they now call "home". They can also be presented at the Patrimonial Week of Pelotas and at academic events, combining practice and theory.

Furthermore, the itineraries can be forwarded to Pelotas Economic Development and Tourism Bureau and to local tour guides, in order to continue the study and as a way of contributing to the development of tourism and gastronomy in Pelotas.

\section{REFERENCES}

Beuchamp, J., Pagel, S. D. \& Do Nascimento, A. R. (2007). Ensino Fundamental de nove anos: orientações para a inclusão de criança de seis anos de idade. Brasília: Ministério da Educação.

Da Costa, M. M. (n.d.). Saber III - Ensinar 
maior interação entre os cursos de Turismo e Gastronomia, visto que os alunos puderam trocar experiências a partir dos conhecimentos individuais prévios de cada área.

Há importância na integração das áreas através da interdisciplinaridade, que neste trabalho é apresentada através dos roteiros, pois integra e incrementa o turismo de uma cidade ou região.

A ludicidade - que facilita o aprendizado na educação turística - foi utilizada como método de ensino-aprendizado, visando um melhor aproveitamento da disciplina. A elaboração dos roteiros e do jogo motivou os alunos a serem mais criativos, ampliando a visão dos mesmos em relação a cidade de Pelotas. Muitos nunca tinham participado de um projeto de criação de jogo, nem mesmo na elaboração de um roteiro. Acredita-se que tal prática influenciará na qualidade da educação e na atuação dos futuros profissionais - tanto do turismo, quanto da gastronomia - no mercado.

Com intenção de que o jogo ultrapasse as paredes da universidade, acreditamos que o jogo possa ser utilizado no projeto Ludoteca do Turismo do Curso de Bacharelado em Turismo, o qual objetiva elaborar material lúdico pedagógico relacionado à área de turismo para utilização em ações educacionais voltadas ao turismo, em escolas de ensino fundamental e comunidade em geral ampliando o público alvo.

Os roteiros elaborados pela turma poderão também ser apresentados aos novos alunos da Universidade, em especial aos alunos que não são da cidade de Pelotas, para que conheçam um pouco mais sobre o destino que agora chamam de "casa". Podem também ser apresentados na Semana do Patrimônio de Pelotas e em eventos acadêmicos aliando a prática com a teoria.

Além disso, as propostas de roteiros através da disciplina de Turismo Gastronômico poderão ser repassadas à Secretaria de Desenvolvimento Econômico e Turismo de Pelotas, bem como para guias locais de turismo, a fim de dar seguimento ao estudo, como forma de auxiliar no desenvolvimento do turismo e da gastronomia da cidade de Pelotas. a Condição Humana: A Ludopoiese na vida do Educador Infantil. Retrieved from www.uece.br/setesaberes/anais/pdfs/ trabalhos/26-07082010-185244.doc

Falkembach, G. \& Morgental, A. (n.d.). O Lúdico e os Jogos Educacionais. Retrieved from http://penta3.ufrgs.br/midiasedu/ modulo13/etapa1/leituras/arquivos/ Leitura_1.pdf

Ferreira, A. F., Vasconcelos, A. K. da C., Gomes, C., Barbosa, V. \& Da Rocha, M. G. (2004). O lúdico nos adultos: um estudo exploratório nos frequentadores do CEPE Natal/RN. HOLOS, 2(20), 1-7.

Fonseca Filho, A. S. (2007) Educação e Turismo: Reflexões para Elaboração de uma Educação Turística. Revista Brasileira de Pesquisa em Turismo, 1(1), 5-33.

Pires do Santos, S. M. (1997). Brinquedoteca: O lúdico em diferentes contextos. Petrópolis: Editora Vozes.

Tarouco, L. M. R., Konrath, M. L. P., Grando, A. R. da S. (2005). O aluno como coconstrutor e desenvolvedor de jogos educacionais. Novas Tecnologias CINTEDUFRGS na Educação, 3(2), 1-8.

\section{REFERÊNCIAS}

Beuchamp, J., Pagel, S. D. \& Do Nascimento, A. R. (2007) Ensino Fundamental de nove anos: orientações para a inclusão de 
criança de seis anos de idade. Brasília: Ministério da Educação.

Da Costa, M. M. (n.d) Saber III - Ensinar a Condição Humana: A Ludopoiese na vida do Educador Infantil. Retirado de www.uece.br/setesaberes/anais/pdfs/ trabalhos/26-07082010-185244.doc

Falkembach, G. \& Morgental, A.,(s/d) O Lúdico e os Jogos Educacionais. Retirado de http://penta3.ufrgs.br/midiasedu/ modulo13/etapa1/leituras/arquivos/ Leitura_1.pdf

Ferreira, A. F., Vasconcelos, A. K. da C., Gomes, C., Barbosa, V. \& Da Rocha, M. G. (2004). O lúdico nos adultos: um estudo exploratório nos freqüentadores do CEPE - Natal/RN. HOLOS, 2(20), 1-7.

Fonseca Filho, A. S. (2007) Educação e Turismo: Reflexões para Elaboração de uma Educação Turística. Revista Brasileira de Pesquisa em Turismo, 1(1), 5-33.

Pires do Santos, S. M. (1997). Brinquedoteca: O lúdico em diferentes contextos. Petrópolis: Editora Vozes.

Tarouco, L. M. R., Konrath, M. L. P., Grando, A. R. da S. (2005) O aluno como co-construtor e desenvolvedor de jogos educacionais. Novas Tecnologias CINTED-UFRGS na Educação, 3(2), 1-8.

\section{APÊNDICES E/OU ANEXOS - APPENDICES}

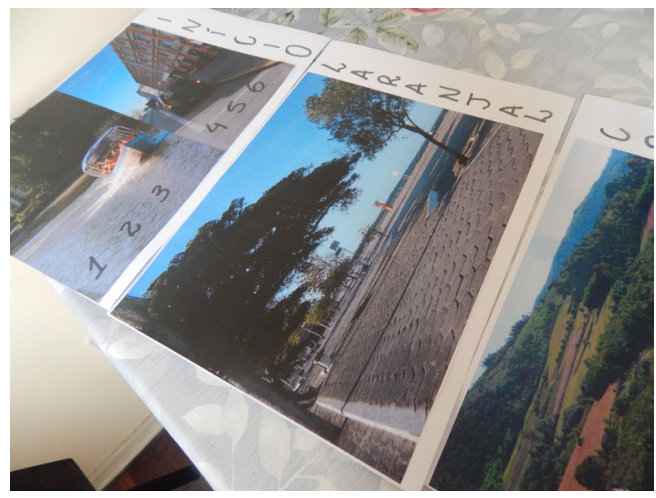

FIGURA 1 - Casas do tabuleiro. Fonte: Fotografia das autoras, 2016

FIGURE 1 - Board squares. Source: Photo by the authors, 2016

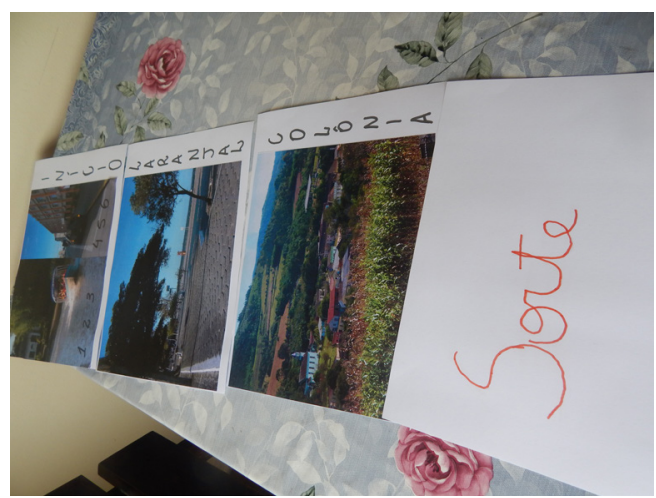

FIGURA 3 - Casas de "Sorte ou Azar". Fonte: Fotografia das autoras, 2016

FIGURE 3 - "Chance" square. Source: Photo by the authors, 2016

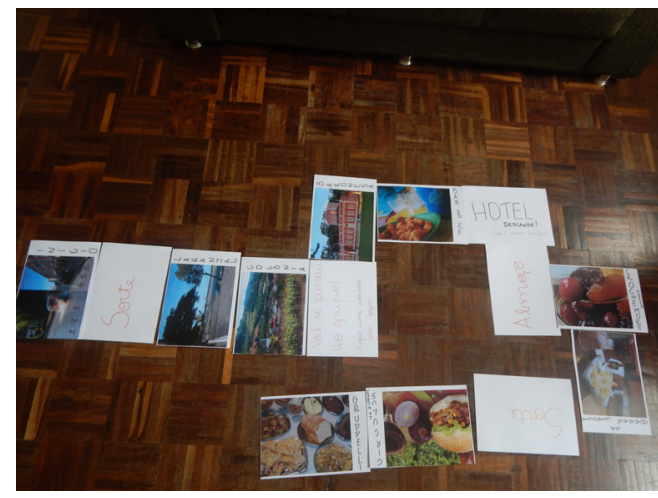

FIGURA 2 - Jogo montado para ser jogado. Fonte: Fotografia das autoras, 2016

FIGURE 2 - Game ready to be played. Source: Photo by the authors, 2016

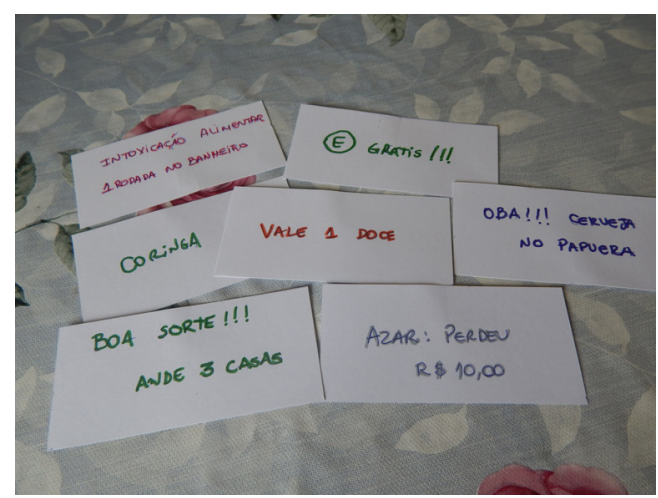

FIGURA 4 - Cartas referentes às casas "pegadinhas". Fonte: Fotografia das autoras, 2016 FIGURE 4 - "Trap" square cards. Source: Photo by the authors, 2016 